\title{
Causes and Effect High Hemodialysis Patients Not Served in Bangil Hospital
}

\author{
Fitri Indahyanti ${ }^{1}$, Tatong Harijanto ${ }^{2}$, Arma Roosalina ${ }^{3}$ \\ ${ }^{1}$ Correspondence Author: findahyanti@yahoo.co.id \\ 1 Master of Hospital Management Faculty of Medicine Universitas Brawijaya, Malang, Indonesia \\ ${ }^{2}$ Master of Hospital Management Faculty of Medicine Universitas Brawijaya, Malang, Indonesia \\ ${ }^{3}$ Regional Public Hospital Bangil, Pasuruan, Indonesia \\ I N D E X I N G
}

Keywords:

Hemodialysis;

Causative Factors;

Bangil Hospital
Kata kunci:

Hemodialisis;

Faktor Penyebab;

Rumah Sakit

Hospital

\begin{abstract}
A B S T R AC T
One of the excellent services at Bangil Pasuruan Regional Hospital is the hemodialysis unit service, from 2017 to August 2019, the number of patients not receiving hemodialysis services is still high. This study aims to determine the factors that cause the high number of patients who do not get hemodialysis services. Type of descriptive qualitative research. Primary data were obtained from interviews with a sample of six people consisting of the head of the hemodialysis unit, the head of service, the head of outpatient services, the head of inpatient services, the head of the education section and the training section and the head of the personnel department. Secondary data were obtained from document studies, observations, and literature. Data was taken from August to October 2019, and fishbone analysis was conducted. The results found eight causative factors, namely no policy for the development of hemodialysis units, no general practitioners of dialysis experts, lack of trained dialysis nurses, no 24hours service policy and cito hemodialysis, limited space and machine capacity, training budget and development of hemodialysis yet prioritized, and hemodialysis training waits for a long time.
\end{abstract}

Salah satu layanan unggulan di RSUD Bangil Pasuruan adalah layanan unit hemodialisis, dari tahun 2017 hingga Agustus 2019, jumlah pasien yang tidak mendapatkan pelayanan hemodialisis masih tinggi. Penelitian ini bertujuan untuk mengetahui faktor-faktor penyebab tingginya jumlah pasien yang tidak mendapatkan pelayanan hemodialisis. Jenis penelitian deskriptif kualitatif. Data primer diperoleh dari wawancara dengan sampel enam orang yang terdiri dari kepala unit hemodialisis, kepala bidang pelayanan, kepala bagian layanan rawat jalan, kepala bagian layanan rawat inap, kepala seksi pendidikan dan bagian pelatihan serta kepala bagian kepegawaian. Data sekunder diperoleh dari studi dokumen, observasi, dan literatur. Data diambil dari Agustus hingga Oktober 2019, dan dilakukan fishbone analysis. Hasil penelitian menemukan delapan faktor penyebab, yaitu tidak ada kebijakan untuk pengembangan unit hemodialisis, tidak ada dokter umum ahli dialisis, kurangnya perawat dialisis terlatih, tidak ada kebijakan layanan 24 jam dan hemodialisis cito, kapasitas ruang dan mesin terbatas, anggaran pelatihan dan pengembangan hemodialisis belum diprioritaskan, dan pelatihan hemodialisis menunggu waktu lama.

$\overline{\text { Article History: Received } 5}$ Feb 2020; Revised 15 Mar 2020; Accepted 25 Apr 2020

(C) 2020 JMMR. All rights reserved

\section{INTRODUCTION}

Chronic kidney disease (CKD) a progressive disorder of kidney function, is irreversible and causes the body to fail to maintain metabolism and fluid and electrolyte balance, resulting in uremia (Smeltzer et al, 2008). Chronic kidney disease consists of several stages, the final stage of chronic kidney disease is called end stage renal disease (ESRD). Late stage kidney disease is indicated by the inability of the kidneys to maintain body homeostasis (Ignativus, 2010).

Chronic kidney disease (CKD) is a global public health problem with an increased prevalence and incidence of kidney failure, poor prognosis and high costs (Pernefri, 2017). 
The increase in the number of CKD patients is in line with the increasing number of elderly population. The global PGK prevalence is $13.4 \%$. According to the results of the global burden of disease in 2010, CKD was the 27th leading cause of death in the world in 1990 and increased to 18th in 2010 (Kemenkes, 2017).

Data from the World Health Organization or the World Health Organization (WHO), the number of people receiving kidney replacement therapy known as renal replacement therapy (RRT), one of which is hemodialysis (HD), is estimated at more than 1.4 million people, with an incidence an incidence of around eight percent per year(Susilo H, 2016)

According to (Pernefri, 2018), in Indonesia the number of new CKD patients undergoing hemodialysis continues to increase from year to year. The number of new patients in 2017 was recorded at 30,831 people, the number doubled in 2018 to 66,433 people. Increasing the number of CKD patients undergoing hemodialysis is not proportional to the number of HD units in Indonesia. The limitations of this hemodialysis service unit result in a high patient waiting list (Kemenkes, 2018).

According to the Indonesian Renal Registry, chronic kidney disease (CKD) is a global health problem with a high burden of health costs, while the number of patients with chronic kidney failure continues to increase from year to year. Kidney failure is the second catastrophic disease that costs the most health after heart disease(Pernefri, 2017).

According to IRR, the number of new patients continues to increase from year to year in line with the increasing number of hemodialysis units, new patients are patients who first had dialysis in 2017 while active patients are all new patients both in 2017 and old patients from the previous year who are still undergo routine hemodialysis and are still alive until December 31, 2017. In 2017 active patients increased sharply, it shows that more patients can undergo longer hemodialysis, JKN factors seem to play a role in maintaining the continuity of this therapy(Pernefri, 2018)

One of the treatment option for CKD patients is hemodialysis. Hemodialysis is carried out to remove metabolic remnants or certain poisons from human blood circulation, such as excess urea, creatinine, gout, and other substances through a semipermeable membrane. CKD patients undergo hemodialysis as much as two to three times a week, each time the average hemodialis takes between four to five hours (Rahman and Kaunang, 2016).

According to IRR 2017, from year to year the number of CKD patients shows an increasing trend, meanwhile the number of hemodialysis service units in Indonesia is not proportional to increase the number of CKD patients (Pernefri, 2017).

Bangil Regional Hospital is a class B hospital, owned by the Pasuruan Regency Government, BLUD status (Bangil, n.d.). Preliminary studies on August 3 to August 31, 2019 from observing quality indicator data and hospital service performance results obtained obtained several problems related to the achievement of quality results that have not met the targets and problems of service visits. The problems were determined prioritization and scoring through focus group discussions (FGD). The selected FGD results are that the hemodialysis unit service is not yet optimal due to the high number of patients who have not been served by hemodialysis.

Data on CKD patient visits undergoing HD experience an increasing trend in the number of new patient visits from 2017 to August 2019 in table 1. 
Table 1. Data on hemodialysis patient visits in Bangil Hospital in 2017 through August 2019

\begin{tabular}{|c|c|c|c|}
\hline \multirow{2}{*}{ Description } & \multicolumn{3}{|c|}{ Year } \\
\cline { 2 - 4 } & 2017 & 2018 & 40 \\
\hline Number of new patients & 30 & 0 & 2910 \\
\hline Number of Routine Patients & 2153 & 3665 & 2950 \\
\hline Total & 2183 & 3665 & (until August) \\
\hline
\end{tabular}

Source: Annual Report of Bangil Hospital in 2019

Data on hemodialysis patients who have not been served from 2017 to August 2019 in Figure 1.

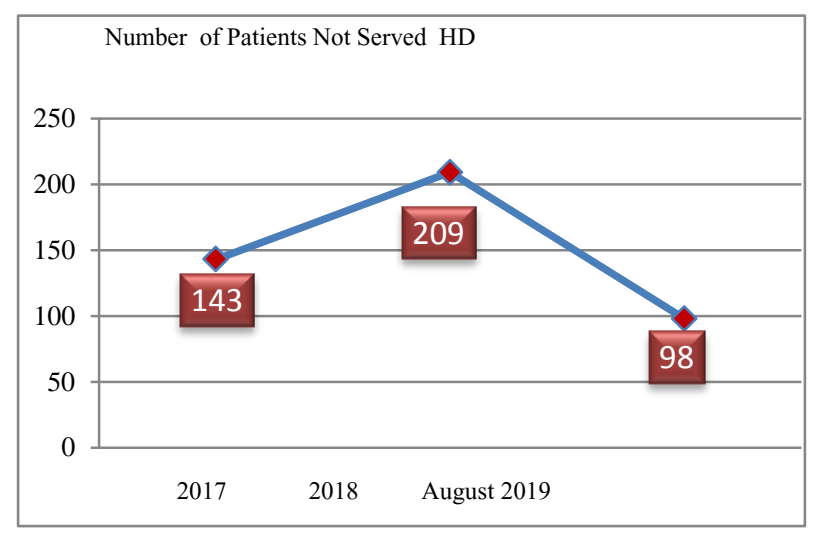

Figure.1 Number of patients not served hemodialysis

The high number of patients who have not been served by hemodialysis at Bangil Regional Hospital shows that the achievement of performance indicators as hospitals owned by the Pasuruan Regency Government has not been fulfilled optimally and the hospital vision has not been fulfilled, namely a professional and customer-oriented hospital, prioritizing patient quality and safety. The quality of service that has not been fulfilled will affect the results of the Government Agency Performance Accountability (SAKIP) assessment system for Bangil Regional Hospital. This study aims to determine the factors causing the high number of patients who are not served by hemodialysis. The results of the study are expected to be a recommendation in the development of hemodialysis units in Bangil Regional Hospital.

\section{RESEARCH METHOD}

This research uses descriptive qualitative research methods. The stages of the research are identification of the problem, determining the cause of the problem, determining the root of the problem. The stages are carried out based on the timeline through focus group discussions (FGD), interviews, document review, field observations and literature review. The first FGD was conducted to determine the priority of hospital problems, carried out in the management meeting room, interviews were carried out unstructured, separately in the informants' workspace, and document review was carried out in the hemodialysis unit and in the management section

The focus group discussion (FGD) was conducted twice, first in the meeting room of the management office, the aim was to determine the priority of the problem to be 
determined for the problem of hemodialysis services and the second meeting to determine the root cause of the problem related to the high number of patients not receiving hemodialysis. The FGD was attended by the 1) Head of Hemodialysis Unit, 2) Head of Services, 3) Head of Support, 4) Head of Outpatient and Inpatient Services, 5) Head of Education and Training, 6) Quality and Nursing Section, 7) Head of Program and Evaluation Section and 8) Program Sub-Section Head and General Staffing.

Unstructured interviews were conducted to find out and explore information related to hemodialysis service inputs, processes and outputs. The informants interviewed were the head of the hemodialysis unit (informant 1), the head of the service sector (informant 2), the head of the outpatient service section (informant 3), the head of development (informant 4), the head of the inpatient service section (informant 5) and the head of the training section (informant 6). The instrument used by using the interview guidelines includes 5 why questions based on the components of man, money, material, machine, method, environment and then an analysis is carried out using the fishbone analysis method.

Document review is carried out to find out data related to hemodialysis service policy, hemodialysis unit service guidelines, hemodialysis unit organization guidelines, hemodialysis unit operational procedure standards (SPO), hemodialysis related regulations namely ministerial health regulations, and report data and activity books in the hemodialysis unit including patient visit data and data on the needs of Bangil District Hospital utility system.

Observations were made to determine the stages of input, process, and output of hemodialysis service activities, which were observed by proficient dialysis nurses, during morning and afternoon shift services, observing the presence of machines and the number of beds in hemodialysis units, instruments used to check the completeness of facilities and number of HR. Literature studies are used to compare conditions in the unit with theories or regulations related to hemodialysis.

Measuring instruments used are interview guidelines, observation guidelines and hemodialysis unit checklist. The measurement results are known to the suitability of the input, process and output with the standard regulations related to the hemodialysis unit.

\section{RESULT AND DISCUSSION}

The results of the data obtained are divided into primary data and secondary data. Primary data were obtained from interviews with several informants to find and explore information related to hemodialysis services ranging from inputs, processes, outputs in hemodialysis units of Bangil Regional Hospital. Secondary data were obtained from document review, observation and literature study.

The Factor that cause the high number of patients not served by hemodialysis from interviews with informants 2 is there was no policy for the development of hemodialysis units to address the problem of hemodialysis services, because hospitals have not yet conducted a review of hemodialysis development.

According to informant 2: "indeed the hospital has not yet made a policy for hemodialysis development, in fact we already know that many patients cannot be served by hemodialysis because the number of our machines is still lacking"

Another contributing factor, according to informant 1 , is that the capacity of hemodialysis units is insufficient to be added to hemodialysis machines, the capacity of the room is only able to accommodate 8 units, whereas the number of cases of patients requiring hemodialysis is increasing. 
According to informant 1: "Our room capacity can only accommodate 8 units of docking machines, in fact we have 9 machines, but one machine is used to back up when there are other machines having problems"

According to informant 3 , the cause of the high number of HD patients not being served was due to the lack of machines, while the number of patients was not lacking: "Patient visit data actually goes down, but for HD services it does not go down, instead many are pivoting, because we have limited number of machines"

According to informant 4 , the main obstacle is the high number of patients who are not served due to the lack of hemodialysis machines, resulting in a lack of hemodialysis expert nurses and the need for room development: "The number of machines is indeed lacking, later it will be developed with the addition of engine, power and room development"

According to informant 5, one of the reasons is the waiting time for hemodialysis officers training that have to wait in line, we plan to take nurses from the inpatient unit,: "This hemodialysis training need more or less a year to wait and finally we take nurses from hospitalization""

According to informant 6 , at the beginning of the opening of HD services, the hospital actually have chosen a doctor to participate in HD training, but later on the doctor couldn't join to the hospital because he had to move to another place following his family,: "In the past there was a doctor who has been trained in hemodialysis, but now he has moved from the Bangil Regional Hospital, and now there is no trained hemodialysis doctor in Bangil Hospital, later on we have to prepare a doctor to be trained "

Observation in hemodialysis units, hemodialysis room capacity can only accommodate 8 (eight) units of machines with patient beds. The number of nurses proficient in dialysis per shift are 4 people in the morning, 3 people in the afternoon. There is no general practitioner on duty in the hemodialysis unit, the specialist in internal medicine does not come every day in the hemodialysis unit.

The results of observations of the hemodialysis service process, if the patient is a new patient category, then for the initial examination / assessment will be carried out by internist, then performed hemodialysis action. Furthermore, for a repeat hemodialysis visit, if the patient's condition is no problem, then the patient is immediately taken an hemodialysis action, without having to be examined by the doctor, only an examination by a nurse. If there are conditions that change or have problems in patients who will be done hemodialysis, then the nurse will report to a specialist in internal medicine about the patient's condition to get advice on action, whether it will be continued or postponed for hemodialysis. Each patient needs 4-5 hours of hemodialysis action. The outputs of hemodialysis patient services have experienced clinical improvement, some have experienced clinical deterioration and some have died.

The data analyzed included organizing guidelines and hemodialysis unit service guidelines, there were already specialist doctors in dialysis as the responsible person, the number of dialysis proficient nurses amounted to 7 according to the results of observations, data on patient visits conducted by hemodialysis every month and data of patients who were not served hemodialysis, there are already several SPOs owned as the basis for action or service, but there is no 24-hour service policy, the services provided are still 2 shifts, namely morning and evening shifts, each shift requires 8-hour service time. SPO data checking services, there is no cito hemodialysis procedure if there are patients who are served outside the shift. 
Reviewing patient visit data at the emergency department, patients with the diagnosis of chronic kidney disease (CKD) approximately 30 percent come at night.

All data obtained were arranged and sorted based on the fishbone analysis model to find out the causes and root causes of the problem as shown in Figure 2

There are several causative factors that have been found for the high number of patients who have not been served by hemodialysis, the main contributing factor is the absence of development policies for hemodialysis units, the current condition of hemodialysis units that can only accommodate 8 units of the machine, insufficient space capacity becomes the dominant factor cannot be added to the engine unit to support hemodialysis services. Other conditions that cause factors are the limited number of human resources (HR), such as dialysis proficient nurses and dialysis specialists who do not yet exist.

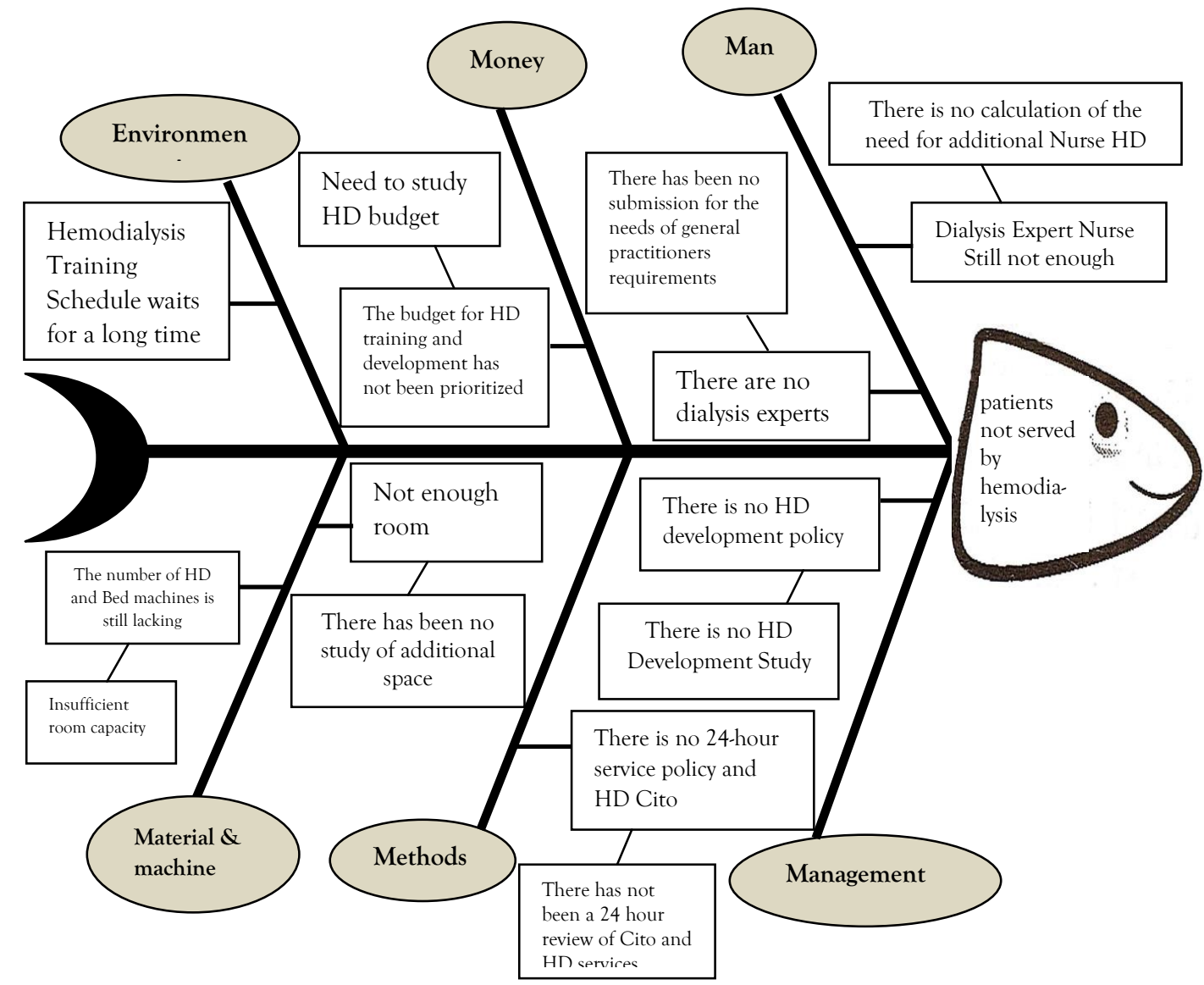

Figure.2 Fishbone analysis of patients who are not served by hemodialysis

Man making factors, the number of dialysis proticient nurses in the hemodialysis unit currently amounts to 7 (seven) with 8 (eight) units of the machine, if the hemodialysis unit serves hemodialysis actions only in the morning shift, then the human resource needs are sufficient, or meet the standards, but if the services performed in a day of 2 (two) shifts, the number of dialysis proficient nurses who guard each shift is still lacking or not standard and not in accordance with the provisions (KEMENKES, 2010), regarding the Organization of Dialysis Services in Health Service Facilities) that for hemodialysis services every 4 (four) machines needed 3(three) nurses. Therefore the hospital needs to increase the need for dialysis proficient nurses by 5 people.

The factor of lack of energy has an impact on the high number of patients who are not served by hemodialysis. The root of the problem is the lack of human resources because there 
has not been a study on the development of the Hemodialysis unit so that the basis for the addition of dialysis personnel cannot be realized. According to (Susilo H, 2016), for the development of a hemodialysis unit in a Special Hospital in Jakarta, it is necessary to add an HR skilled in dialysis nurses so that the weaknesses of the internal hospital can be found.

Services in the hemodialysis unit of Bangil Regional Hospital also do not yet have a general practitioner who have a hemodialysis certificate, according to (Pernefri, 2003) the presence of a general practitioner is needed by the hemodialysis unit. General practitioners are required to be able to serve hemodialysis patients every day during the hemodialysis service process.

Practitioner is an attempt to delegate authority in the form of a mandate from a specialist in the dialysis expert as the person in charge of hemodialysis. (Sarah Andini, 2013) Although general practitioners have been competent to carry out hemodialysis, the responsibility and supervision of hemodialysis in hospitals remains with specialists in hypertension kidney consulants and / or trained internal medicine specialists with certified dialysis. (Ranny, 2016)

Factors making up the Method, the absence of 24-hour policy and hemodialysis Cito service procedures to be one of the causes of patients not served hemodialysis, because Bangil Hospital only serves morning shifts and afternoon shifts, from data obtained at the emergency department (IGD) on the night shift, the number patients who are not served by hemodialysis and have a referral of approximately 30 percent. If the hospital serves hemodialysis within 24 hours it will reduce the number of patients who are not served. The root cause of the problem is the absence of such a policy because there has been no study of hemodialysis unit development (Susilo H, 2016). Hemodialysis is carried out at Bangil District Hospital twice a week, the application of this rule is in accordance with a journal that states that there is no significant benefit for carrying out hemodialysis three times a week $(\mathrm{Jr}$, 2012).

The constituent factors of material and machine, the causative factors of material are the limited hemodialysis space capacity, according to Pernefri's standard for 1 patient compared to an area of $8 \mathrm{~m} 2$. The wide hemodialysis unit of Bangil Regional Hospital is currently only able to accommodate 8 hemodialysis machines with its beds. The lack of wide hemodialysis units has an effect on increasing the number of patients who are not served by hemodialysis, if the room can accommodate more hemodialysis machines, it will affect the decrease in the number of patients not served by hemodialysis. According to (Susilo H, 2016), the development of hemodialysis in Jakarta Special Hospital, can be done by adding hemodialysis space and machinery facilities needed, this is to support operations and meet customer expectations. Hemodialysis machines and tools become the most important patient needs that need to be improved by the hospital, especially the hemodialysis unit (Siregar et al., 2017).

Management factors, the cause of the absence of hemodialysis unit development policy or program policies are the main factors that greatly affect the high number of patients who are not served by hemodialysis. Regulation is the basis of an organization to carry out an activity. If there are no regulations from hospitals to develop hemodialysis units, the number of patients not served by hemodialysis remains high or even increased. 
The root cause of the problem is because the hospital has not yet conducted a hemodialysis unit development study.

According to (Susilo H, 2016), in determining the decision making for developing a hemodialysis unit are based on market analysis or SWOT analysis and financial analysis.

According to (Susilo H, 2016), hemodialysis development policy in Jakarta Special Hospital can be done by covering the internal weaknesses of hospitals, the development of hemodialysis units is needed to increase hospital revenue or revenue center and improve service quality and patient satisfaction.

The constituent factors of Money, the causes of hemodialysis development have not been budgeted because there has not been a study of hemodialysis unit development. According to (Susilo H, 2016), the development of hemodialysis units requires an adequate financial planning.

The constituent environment factors are the cause of the lack of prioritization of hemodialysis proficiency training because there have been no studies on the development of hemodialysis units and so far, to include nurses in hemodialysis training must wait quite a long time of about one year.

\section{CONCLUSION}

There are eight causative factors found. The main contributing factor is that of the drafting management, there is no policy (policy) for the development of HD units, other factors namely dialysis expert general practitioners are not available, the lack of skilled dialysis nurses. there is no 24-hour service policy and cito hemodialysis procedure, HD space and engine capacity is limited, the budget for HD training and development has not been prioritized, HD training is waiting a long time of approximately one year. The absence of a policy on developing a hemodialysis unit has an impact on the number of patients not being served by hemodialysis.

\section{REFERENCE}

Bangil, R. (n.d.). Laporan Tahunan RSUD Bangil Kabupaten Pasuruan Tahun 2018.

Clinical Nursing Competencies of Caring for Hansen's Disease Survivors During the Final Career Stage of Nurses' Development in Japan. (2015). NAKAYAMA.

Ghanbari, A., Hasandoost, F., Lyili, E., Khomeiran, R., \& Momeni, M. (2017). See all , 10 Citations See all , 22 References Download citation Share Download full-text PDF Assessing Emergency Nurses' Clinical Competency: An Exploratory Factor Analysis Study. Iranian_journal_of_nursing_and_midwifery_research, 22(4), 280.

Haryati Eko. (2010). Asuhan Keperawatan Chronic Renal Failur.

Hermalia, I. (2019). Kompetensi Perawat Hemodialisis. Jurrnal Keperawatan Komprehensif, 5.

Ignativus. (2010). Medical-Surgical Nursing: Clients - Centered Collaborative Care (Sixth Edit). Saunders.

Ilyas. (2011). Perencanaan SDM Rumah Sakit, Teori, Metoda dan Formula. Pusat Kajian Ilmu Kesehatan FKM-UI. CV Usaha Prima 2011.

Jr, E. L. (2012). Survival with Three-Times Weekly In-Center Nocturnal Versus Conventional Hemodialysis. Journal American Society of Nephrology, 23, 687-695.

KEMENKES. (2010). Permenkes Nomor 812/ Menkes/PER/VII/2010 tentang Penyelenggaraan Pelayanan Dialisis pada Fasilitas Pelayanan Kesehatan.

Kemenkes. (2017). InfoDATIN.

Kemenkes. (2018). Info Datin. 
Lenberg, C. (2009). The COPA model: A comprehensive framework designed to promote quality care and competence for patient safety. Pubmed, 5.

Pernefri. (2003). Konsesnsus Dialisis, Perhimpunan Nefrologi Indonesia (1st ed.).

Pernefri. (2017). 10th Report Of Indonesian Renal Registry 2017.

Pernefri. (2018). 10th Report of Indonesian Renal egistri.

Rahman and Kaunang. (2016). Hubungan antara lama menjalani hemodialisis dengan kualitas hidup pasien yang menjalani hemodialisis di Unit Hemodialisis RSUP. Prof. Dr. R. D. Kandou Manado. Jurnal E-Clinic (ECl), 4.

Ranny. (2016). Kompetensi Sumber Daya Manusia dalam Penyelenggaraan Hemodialisis di Rumah Sakit Dihubungkan dengan Asas Perlindungan Hukum. SOEPRA Jurnal Hukum Kesehatan Universitas Katolik Soegijapranata Semarang, 2(1).

Sarah Andini. (2013). Analisa Kebutuhan Tenaga Keperawatan Di Instalasi Hemodialisa Rumah Sakit Umum Pusat Persahabatan Berdasarkan Beban Dan Kompetensi Kerj.

Siregar, K., Ginting, R., Siregar, I., Industri, D. T., Teknik, F., \& Utara, U. S. (2017). Penyusunan Kebutuhan Perancangan Mesin Hemodialisis Menggunakan Kansei Engineering Serta Aplikasi QFD dan TRIZ. 12(1), 1-9.

Smeltzer et al. (2008). Buku Ajar Keperwata Medikal Bedah. Kedokteran EGC.

Susilo H. (2016). Analisis Kelayakan Pengembangan Unit Hemodialisis Rumah Sakit Khusus Jakarta. Universitas Gajah Mada. 